\title{
Assessment of Nutrient Composition and Antioxidant Activity of Some Popular Underutilized Edible Crops of Nagaland, India
}

\author{
Chitta Ranjan Deb* ${ }^{\circledR}$, Neilazonuo Khruomo \\ Department of Botany, Nagaland University, Lumami, India \\ Email: ^debchitta@rediffmail.com, ^debchitta@gmail.com
}

How to cite this paper: Deb, C.R. and Khruomo, N. (2021) Assessment of Nutrient Composition and Antioxidant Activity of Some Popular Underutilized Edible Crops of Nagaland, India. Natural Resources, 12, 44-58.

https://doi.org/10.4236/nr.2021.122005

Received: December 25, 2020

Accepted: February 23, 2021

Published: February 26, 2021

Copyright $\odot 2021$ by author(s) and Scientific Research Publishing Inc. This work is licensed under the Creative Commons Attribution International License (CC BY 4.0).

http://creativecommons.org/licenses/by/4.0/

\begin{abstract}
In Nagaland $\sim 70 \%$ of population lives in rural areas and depends on forest products for livelihood. Being part of the biodiversity hotspot, state is rich in biodiversity. The present study was an attempt made to understand the nutritional properties of 22 popular underutilized edible plants (UEP) Kohima, Phek, Tuensang districts. Results revealed moisture content of 22 studied plants ranged between 4.8 to $88.15 \mathrm{~g} / 100 \mathrm{~g}$, while protein content varied between $0.00269-0.773 \mathrm{~g} / 100 \mathrm{~g}$ with highest in Terminalia chebula $(0.773 \mathrm{~g} / 100 \mathrm{~g})$ fruit while lowest protein content was in Setaria italica $(0.00269 \mathrm{~g} / 100 \mathrm{~g})$. Total carbohydrate content was between $0.198-5.212 \mathrm{~g} / 100 \mathrm{~g}$ with highest in Setaria italica $(5.212 \mathrm{~g} / 100 \mathrm{~g})$ and lowest in Juglans regia $(0.198 \mathrm{~g} / 100 \mathrm{~g})$. Of the 22 samples, maximum antioxidant activity was in Terminalia chebula fruits $(37.49 \mu \mathrm{g} / \mathrm{ml})$ followed by Clerodendrum glandulosum $(65.29 \mu \mathrm{g} / \mathrm{ml})$ leaves, Phyllanthus emblica $(79.08 \mu \mathrm{g} / \mathrm{ml})$ fruits against Trolox $(96.89 \mu \mathrm{g} / \mathrm{ml})$. Highest total phenol content (TPC) was recorded in Terminalia chebula $(53.11 \mathrm{mg}$ GAE/g) and Rhus chinensis (43.99 mg GAE/g) while in other 20 crops the values varied from $0.09-8.44 \mathrm{mg}$ GAE/g. Total flavonoid content (TFC) varied between $0.004-43.67 \mathrm{mg}$ QE/g with clerodendrum glandulosum (43.67 $\mathrm{mg} \mathrm{QE} / \mathrm{g}$ ) and Terminalia chebula (27.78 mg QE/g) were found to be highest among the 22 plant samples. Findings suggest that these underutilized edible plants should be popularized as they can contribute to nutritional support to different region of the state for health improvement and cultivated them commercially to help and develop various value added local product to improve the livelihood status of the rural population and also add to the economy of the state and region.
\end{abstract}

\section{Keywords}

Antioxidant Activity, Food Security, Nagaland, Nutrient, Rural Health, 
Underutilized Edible Plants

\section{Introduction}

Underutilized edible plants are under exploited of its potential for contributing to food security (nutritional/medicinal), income generation and environmental services [1]; they are locally abundant instead of globally, lack scientific knowledge concerning their physiological, agronomic and ecological properties and have a limited current use relative to their economic potential. They have the potential to fight against poverty and starvation faced by many developing countries and can help promote crop diversification to encounter such problems and also improve the rural economy [2] [3]. Though they are not significant in terms of global production and consumption systems but are rich in macronutrients and micronutrients and comparatively they require relatively low inputs thereby contributing to rural sustainable agricultural production and combating the "hidden hunger" caused by micronutrients deficiencies [2] [3] [4] [5]. They have the capability to deliver many health benefits apart from fulfilling physiological needs and had been conferred the status of functional foods [6].

A diet rich in higher antioxidant activities with free radical scavenging molecules (flavonoids, anthocyanins, cartenoids, and dietary glutathionine), vitamins and endogenous metabolites can protect the human body against cellular oxidation reactions, cardiovascular events, cancer, and other age-related degenerative diseases [7] [8] [9]. Fruits, nuts and vegetables play a significant role in human nutrition especially as source of vitamins, minerals and dietary fiber [10]. They offer advantages over dietary supplements because of low cost and wide availability; as such they remain an important source of nutrients in many parts of the world. Nuts are good source of essential fatty acid, fiber, vitamin E and mineral [11]. Some components of fruits and vegetables are strong antioxidants and function to modify the metabolic activation and detoxification/disposition of carcinogens or even influence processes that alter the course of the tumor cell [12]. A high dietary intake of fruits and vegetables is strongly associated with a reduced risk of developing some chronic diseases, such as various types of cancer, cardiovascular disease, type II diabetes and other degenerative or age-related diseases, which causes death in many developed countries was established by clinical trial and epidemiological studies [8]. With the advantages of medical science, people live longer and are faced with diseases that come along with age and illnesses such as cancer and diabetes mellitus [13]. The antioxidants from plant origin are beneficial compared to synthetic ones as they do not have any side effect/genotoxic effect [14] [15], further natural antioxidants are advantageous due to cost effectiveness and easy accessibility in the form of vegetables and fruits [16]. Data on epidemiological and in vitro studies strongly suggest that foods containing phytochemicals with anti-oxidation potential have strong protective effects against 
major disease risks [17] and natural antioxidants in fruits and vegetables have gained increasing interest among consumers and the scientific community because epidemiological studies have indicated that frequent consumption of natural antioxidants is associated with a lower risk of cardiovascular disease and cancer [18]. Potential sources of antioxidant compounds have been searched in several types of plant materials such as vegetables, fruits, leaves, oilseeds, cereal crops, barks and roots, spices and herbs, and crude plant drugs [19]. Phenolic substances such as flavonoids are the most common compounds in fruits and vegetables and have strong antioxidant capacity [20] [21]. Crop improvement has played important role in sustaining and strengthening food and nutrition, health and livelihood in the world from the very beginning of domestication yet millions of people are still under-nourished [22] [23].

Nagaland, a small state of North-Eastern region of India very rich in its flora and fauna. Being a part of Indo-Burma biodiversity hotspot, the region is a home for unique biodiversity and the indigenous Naga tribes depends greatly on forest products as food source and is an integral part of their daily lives [2] [3]. Nagaland is basically an agricultural based state and cultivation of cereal crops plays a big part in agricultural system of the state. Millets and jobs tear are important traditional Naga cereal crops which have been passed down from generation through traditional preservation method. Forest has a large and indispensable role in improving the food security and livelihood of the tribal society [24]. About $70 \%$ of ethnic tribes are living in rural hilly areas and depends on minor forest products for livelihood including food and medicines. During 2012-16 three hilly districts (Kohima, Phek and Tuensang) of Nagaland, India was surveyed for underutilized wild edible plant species and 142 species were collected, documented [3]. Of these 142 species, 22 species were found to be popular among the tribal population. Following documentation, an attempt was made to understand the nutritional properties of these 22 popular underutilized edible plants (UEP).

\section{Materials and Method}

\subsection{Survey Areas}

Kohima District: Kohima is the capital city of Nagaland state, India, located between the geographical coordinates of $25.6701^{\circ} \mathrm{N}$ and $94.1077^{\circ} \mathrm{E}$ surrounded by the Dimapur district to the west, Phek and Zunheboto district to the east, Wokha district to the north and Manipur state to the south with a total geo-

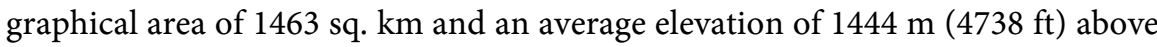
sea level. It is the home land of the Angami Naga tribe and agriculture is the main occupation.

Phek district: Phek district lies in the South-East of Nagaland with geographical coordinate of $25.40^{\circ} \mathrm{N}$ and $94.28^{\circ} \mathrm{E}$, bounded by Kohima district in the west, Zunheboto and Kiphire districts in the North, Myanmar in the South East and Manipur state in the South with an area of $2026 \mathrm{sq} \cdot \mathrm{km}$. The district is inhi- 
bited by the Chakhesang Naga tribe and Puchury tribes with agriculture being the main occupation where $80.84 \%$ of the population engaged in agriculture and Terrace rice cultivation.

Tuensang District: Tuensang district is the largest district of Nagaland with geographical coordinate of $26.14^{\circ} \mathrm{N}$ and $94.49^{\circ} \mathrm{E}$ sharing an international border with Myanmar all along its eastern sector and is bounded by Mon district in the north east, Longleng in the north, Mokokchung in the south. Chang, Sangtam, Yimchunger and Khiamniungan are the main indigenous tribes of the district and Jhum-shifting cultivation is the main agricultural practice of the district.

An extensive field survey was carried out in different seasons during the period 2012-2016. With the help of forest experts and field guides, random collection of plant materials was carried out in study area during the different seasons of the year and also at the peak seasons of the plants. The collected plant materials were then kept in zipper poly bags and brought to the laboratory for identification and carry out nutritional studies.

\subsection{Sample Preparation}

The 22 selected UEP considered for the assessment consists of 2 cereal crops (Coix-Icryma jobi and Setaria italica), 9 leafy vegetables (Centalla asiatica, Clerodendrum glandulosum, Elatostema platyphyllum, Lasia spinosa, Polygonum chinense, Polygonum molle, Trichodesma khasianum, Plantago erosa, Zanthoxylum oxyphyllum) and 11 fruits and nuts (Actinidia callosa, Hodgsonia macrocarpa, Ficus auriculata, Ficus semicordata, Juglans regia, Olax imbricata, Phyllanthus emblica, Rhus chinensis, Spondias pinnata, Stixis suaveolens, Terminalia chebula). Fresh plant samples were harvested during right harvesting period in different seasons from the districts of Kohima, Phek and Tuensang and brought to the laboratory. The plant samples were rinsed with water, air dried and grounded into powder for the assessment. Thereafter, the prepared samples were subjected to analysis for nutritional and phytochemical content and antioxidant properties using different analytical methods. Details of the 22 selected UEP are listed in Table 1 along with the botanical name, common name and the parts used of the plants.

\section{Nutritional Analysis}

\subsection{Proximate Composition}

Moisture content: Moisture content was estimated following Association of Official Agricultural Chemists [25] method with slight modification. Two g of the collected each sample was taken in a separate pre-weighed dish and oven dried at $70^{\circ} \mathrm{C}$ for $\sim 4 \mathrm{~h}$ for leafy vegetables and $\sim 18 \mathrm{~h}$ for fresh fruits, nuts and cereals. The moisture content was calculated by using the formula.

$$
\text { Moisture content }(\%)=\frac{\text { Loss of weight }(\mathrm{g})}{\text { Weight of the sample }(\mathrm{g})} \times 100
$$


Table 1. Twenty two selected underutilized edible plants for nutrient composition assessment.

\begin{tabular}{|c|c|c|c|}
\hline Botanical Name & Family & Common Name & Parts Used \\
\hline \multicolumn{4}{|c|}{ Cereal Crops } \\
\hline Coix-lacryma jobi L. & Poaceae & Job's tears & Seeds \\
\hline Setaria italica (L.) P. Beauv. & Poaceae & Foxtail millet & Seeds \\
\hline \multicolumn{4}{|c|}{ Leafy Vegetables } \\
\hline Centella asiatica (L.) Urb. & Apiaceae & Indian penny wort & Young leaves \\
\hline Clerodendrum glandulosum Lindl. & Verbenaceae & Glory hill bower & Young leaves \\
\hline Elatostema platyphyllum Wedd. & Urticaceae & Elatostema & Young leaves \\
\hline Lasia spinosa (L.) Thwaites & Araceae & Queen flower & Young leaves \\
\hline Plantago erosa Wall. & Plantaginaceae & Common plaintain & Young leaves \\
\hline Polygonum chinense $\mathrm{L}$. & Polygonaceae & Chinese knotweed & Young leaves \\
\hline Polygonum molle D. Don & Polygonaceae & Soft knot grass & Young leaves \\
\hline Trichodesma khasianum C. B. Cl. & Boraginaceae & Trichodesma & Young leaves \\
\hline Zanthoxylum oxyphyllum Edgew & Rutaceae & Badrang (Hin) & Young leaves \\
\hline \multicolumn{4}{|c|}{ Fruits and Nuts } \\
\hline Actinidia callosa Lindl & Actinidiaceae & Wild kiwi & Mature fruit \\
\hline Phyllanthus emblica $\mathrm{L}$. & Euphorbiaceae & Goose berry & Mature fruit \\
\hline Ficus auriculata Lour. & Moraceae & Roxburgh fig & Mature fruit \\
\hline Ficus semicordata Buch.-Ham. ex Sm. & Moraceae & Drooping fig & Mature fruit \\
\hline Hodgsonia macrocarpa (Blume) & Cucurbitaceae & Lard seed & Nut \\
\hline Juglans regia $\mathrm{L}$. & Juglandaceae & Wild walnut & Nut \\
\hline Olax imbricata Roxb. & Olacaceae & Olax & Mature fruit \\
\hline Rhus chinensis Mill. & Anacardiaceae & Nutgall tree & Mature seed \\
\hline Spondias pinnata (L. f.) Kurz & Anacardiaceae & Wild mango & Mature fruit \\
\hline Stixis suaveolens (Roxburgh) Pierre & Capparaceae & Stixis & Mature fruit \\
\hline Terminalia chebula Retz. & Combretaceae & Myrobalan & Mature fruit \\
\hline
\end{tabular}

Protein content. Protein estimation was determined by using the Colorimetric method described by Lowry [26]. About $500 \mathrm{mg}$ of the oven dried sample was grounded and homogenized with $10 \mathrm{ml}$ of $0.1 \mathrm{M}$ Phosphate buffer ( $\mathrm{pH} 7.4)$ and centrifuged the solution at $1000 \mathrm{rpm}$ for $10 \mathrm{~min}$. The supernatant was filtered with Whatman filter paper and the filtrate was used for protein analysis. Pipette out $1 \mathrm{ml}$ of the extract to which $5 \mathrm{ml}$ of the Lowry's regent was added. Mixed the solution well and allowed the mixture to stand for $10 \mathrm{~min}$. Added $1 \mathrm{~N}$ of Folin-ciocalteau reagent to the solution followed by incubation at room temperature in the dark for $30 \mathrm{~min}$. Absorbance was taken at $660 \mathrm{~nm}$ and the standard curve was prepared with Bovine Serum Albumin.

Total carbohydrate: Total carbohydrate was estimated using the Phenol-Sulphuric Acid Method [27]. About $300 \mathrm{mg}$ of sample was weighed and hydrolyzed by keeping it in a boiling water bath for $3 \mathrm{~h}$ with $5 \mathrm{ml}$ of $2.5 \mathrm{~N} \mathrm{HCl}$ and cool to room temperature. The volume was made to $50 \mathrm{ml}$ with distilled water and cen- 
trifuged at $1000 \mathrm{rpm}$ for $10 \mathrm{~min}$ and the supernatant was filtered and the filtrate to be used for the estimation of total carbohydrate. To $1 \mathrm{ml}$ of the extract, added $1 \mathrm{ml}$ of 5\% Phenol solution followed by $5 \mathrm{ml}$ sulphuric acid (96\%) and mixed well by shaking for $10 \mathrm{~min}$. The content of the tube was placed on a water bath $25^{\circ} \mathrm{C}$ to $30^{\circ} \mathrm{C}$ for $20 \mathrm{~min}$ and the absorbance was read at $490 \mathrm{~nm}$ and the standard curve was prepared using glucose.

Reducing sugar estimation: Reducing sugar was estimated using the method of 3,5-dinitrosalicylic acid reagent [28]. One g sample was weighed and grounded with $10 \mathrm{ml}$ of ethanol $(80 \%, \mathrm{v} / \mathrm{v})$ and the solution was centrifuged at $1000 \mathrm{rpm}$ for $10 \mathrm{~min}$, supernatant was then filtered and the filtrate was used for estimation of reducing sugar. To $1 \mathrm{ml}$ of extract $3 \mathrm{ml}$ of DNS reagent was added followed by heating the solution in a boiling water bath for $5 \mathrm{~min}$. Added $1 \mathrm{ml}$ of $40 \%(\mathrm{w} / \mathrm{v})$ Rochelle salt solution (Potassium Sodium Tartrate) in the cooled reaction mixture. The absorbance was read at $510 \mathrm{~nm}$ and compared with the standard curve prepared using glucose.

Preparation of Sample extracts for Antioxidant activity, Total phenol content and Total flavonoid content. Methanolic extraction was prepared for estimation of antioxidant activity, total phenolic content, total flavonoid content. Ten $\mathrm{g}$ of dried sample was grinded in liquid nitrogen using mortar and pestle, powder was mixed with $100 \mathrm{ml}$ of methanol and incubated for $24 \mathrm{~h}$ at $25^{\circ} \mathrm{C}$ under continuous stirring at $150 \mathrm{rpm}$. The process repeated until the extraction solvent became colorless. The extract was then filtered on filter paper Whatman No. 4 and the filtrate was used for analysis.

\subsection{Antioxidant Activity}

DPPH Radical Scavenging Assay: 2, 2-Diphenyl-1-picrylhydazyl (DPPH) stable free radical method was used to determine the antioxidant activity of the plant extract following Aoshima et al. [29]. To $0.1 \mathrm{ml}$ of sample extract with different extract concentrations $(10 \mu \mathrm{g} / \mathrm{ml}, 50 \mu \mathrm{g} / \mathrm{ml}, 100 \mu \mathrm{g} / \mathrm{ml}, 150 \mu \mathrm{g} / \mathrm{ml}, 200$ $\mu \mathrm{g} / \mathrm{ml}), 2.9 \mathrm{ml}$ of DPPH (0.1 mM DPPH prepared in methanol) was added and vortexed vigorously. Incubation of the reaction mixture for $30 \mathrm{~min}$ was done in the dark at $30^{\circ} \mathrm{C}$ and the absorbance of the mixture was measured at $517 \mathrm{~nm}$. Trolox was used as the standard for the evaluation of antioxidant activity. Inhibition of free radical by DPPH was calculated by the following equation:

$$
\begin{aligned}
& \text { DPPH scavenging effect }(\% \text { inhibition }) \\
& =\frac{\text { Control absorbance }- \text { Sample absorbance }}{\text { Control absorbance }} \times 100
\end{aligned}
$$

Total phenolic content: The presence of polyphenols was determined by Folin-Ciocalteu method [30]. The resulting absorbance of the blue colored solution was measured at $765 \mathrm{~nm}$ and the total phenolic content of the mushroom samples were expressed as $g$ of gallic acid equivalents (GAE) per $g$ of the extract.

Total flavonoid content. The flavonoids content was estimated by spectrophotometric method following Sahreen et al. [31]. The absorbance of the solu- 
tion was measured at $510 \mathrm{~nm}$. Quercetin was used as the standard and the results expressed as $g$ of quercetin equivalents (QE) per $g$ of the extract.

\subsection{Statistical Analysis}

All the experiments were carried out in triplicate $(n=3)$ and data expressed as Mean \pm Standard deviation.

\section{Results}

\section{Proximate Analysis}

Moisture content: Table 2 shows the moisture content of the 22 selected

Table 2. Proximate quantification of different nutritional parameters of 22 selected underutilized edible plants.

\begin{tabular}{|c|c|c|c|c|}
\hline \multirow{3}{*}{ Plant Species } & \multicolumn{4}{|c|}{ Parameters ${ }^{*}$} \\
\hline & Moisture & Total Carbohydrate & Reducing Sugar & Protein $(g / 100 g)$ \\
\hline & Content & $(g / 100 g)$ & $(g / 100 g)$ & $(g / 100 g)$ \\
\hline \multicolumn{5}{|c|}{ Cereal Crops } \\
\hline Coix-lacryma jobi & $8.65 \pm 0.33$ & $4.379 \pm 0.03$ & $0.009 \pm 0.001$ & $0.005 \pm 0.0001$ \\
\hline Setaria italic & $16.25 \pm 0.42$ & $5.212 \pm 0.32$ & $0.014 \pm 0.002$ & $0.003 \pm 0.0002$ \\
\hline \multicolumn{5}{|c|}{ Leafy Vegetables } \\
\hline Clerodendrum glandulosum & $72.45 \pm 0.29$ & $1.131 \pm 0.03$ & $0.031 \pm 0.004$ & $0.029 \pm 0.001$ \\
\hline Elatostema platyphyllum & $84.90 \pm 0.18$ & $4.592 \pm 0.009$ & $0.045 \pm 0.004$ & $0.013 \pm 0.0001$ \\
\hline Centella asiatica & $80.75 \pm 0.4$ & $0.587 \pm 0.01$ & $0.036 \pm 0.005$ & $0.153 \pm 0.002$ \\
\hline Lasia spinosa & $50.50 \pm 0.27$ & $0.417 \pm 0.006$ & $0.016 \pm 0.001$ & $0.023 \pm 0.001$ \\
\hline Plantago erosa & $88.15 \pm 0.36$ & $1.72 \pm 0.001$ & $0.057 \pm 0.001$ & $0.184 \pm 0.001$ \\
\hline Polygonum chinense & $85.60 \pm 0.3$ & $3.379 \pm 0.007$ & $0.041 \pm 0.002$ & $0.542 \pm 0.003$ \\
\hline Polygonum molle & $84.75 \pm 0.16$ & $0.768 \pm 0.001$ & $0.081 \pm 0.003$ & $0.072 \pm 0.003$ \\
\hline Trichodesma khasianum & $80 \pm 0.49$ & $0.753 \pm 0.004$ & $0.034 \pm 0.001$ & $0.035 \pm 0.002$ \\
\hline \multirow{2}{*}{ Zanthoxylum oxyphyllum } & $75.30 \pm 0.41$ & $0.57 \pm 0.002$ & $0.041 \pm 0.001$ & $0.027 \pm 0.002$ \\
\hline & \multicolumn{4}{|c|}{ Fruits and Nuts } \\
\hline Actinidia callosa & $83.8 \pm 0.04$ & $5.135 \pm 0.004$ & $0.097 \pm 0.003$ & $0.026 \pm 0.002$ \\
\hline Phyllanthus emblica & $83.2 \pm 0.45$ & $0.895 \pm 0.003$ & $0.059 \pm 0.005$ & $0.439 \pm 0.005$ \\
\hline Ficus auriculata & $78.9 \pm 0.12$ & $3.938 \pm 0.01$ & $0.139 \pm 0.004$ & $0.011 \pm 0.001$ \\
\hline Hodgsonia macrocarpa & $36.95 \pm 0.03$ & $0.321 \pm 0.003$ & $0.012 \pm 0.001$ & $0.038 \pm 0.001$ \\
\hline Juglans regia & $4.8 \pm 0.21$ & $0.198 \pm 0.01$ & $0.009 \pm 0.001$ & $0.019 \pm 0.001$ \\
\hline Olax imbricate & $82.05 \pm 0.12$ & $1.465 \pm 0.03$ & $0.041 \pm 0.001$ & $0.045 \pm 0.001$ \\
\hline Spondias pinnata & $81.85 \pm 0.07$ & $5.135 \pm 0.01$ & $0.0673 \pm 0.001$ & $0.081 \pm 0.001$ \\
\hline Rhus chinensis & $11.5 \pm 0.28$ & $1.402 \pm 0.004$ & $0.019 \pm 0.001$ & $0.098 \pm 0.002$ \\
\hline Stixis suaveolens & $80.2 \pm 0.22$ & $2.279 \pm 0.007$ & $0.049 \pm 0.001$ & $0.146 \pm 0.002$ \\
\hline Terminalia chebula & $68.3 \pm 0.29$ & $1.869 \pm 0.009$ & $0.059 \pm 0.001$ & $0.773 \pm 0.004$ \\
\hline
\end{tabular}

${ }^{*}$ Data represents mean of three replicates $( \pm$ Standard error). 
plants varied significantly ranging from 4.8 to $88.15 \mathrm{~g} / 100 \mathrm{~g}$. The maximum moisture content was recorded in the leafy vegetables which were recorded as 88.15 , 85.6 and $84.9 \mathrm{~g} / 100 \mathrm{~g}$ in Plantago erosa, Polygonum chinense and Elatostema platyphyllum respectively. The moisture content was significantly low in the nuts of Juglans regia recorded as $4.8 \mathrm{~g} / 100 \mathrm{~g}$ and also cereal crop Coix-lacryma jobi and fruit of Rhus chinensis showed very low moisture content which was recorded as 8.65 and $11.5 \mathrm{~g} / 100 \mathrm{~g}$ respectively. Over all, it was found that leafy vegetable samples have the highest moisture content $(50.50-88.15 \mathrm{~g} / 100 \mathrm{~g}$ ) compared to fruit samples (4.8 - 83.8 g/100g) and cereal crop (8.65\% in Coix-lacryma jobi and $16.25 \mathrm{~g} / 100 \mathrm{~g}$ in Setaria italica).

Protein content. Table 2 shows the protein content of the 22 plant sample varied significantly which ranged between $0.00269-0.773 \mathrm{~g} / 100 \mathrm{~g}$ of the sample (D/W basis). The maximum protein content was recorded in the fruits of Terminalia chebula $(0.773 \mathrm{~g} / 100 \mathrm{~g})$ which was followed by leaves of Polygonum chinense $(0.54 \mathrm{~g} / 100 \mathrm{~g})$ and fruits of Phyllanthus emblica $(0.439 \mathrm{~g} / 100 \mathrm{~g})$. The lowest protein content was recorded in the cereal crops Setaria italica $(0.00269 \mathrm{~g} / 100 \mathrm{~g})$, Coix-lacryma jobi $(0.00412 \mathrm{~g} / 100 \mathrm{~g})$ followed by Ficus auriculata fruits $(0.011$ $\mathrm{g} / 100 \mathrm{~g})$, Elatostema platyphyllum $(0.013 \mathrm{~g} / 100 \mathrm{~g})$ and Actinidia callosa $(0.026$ $\mathrm{g} / 100 \mathrm{~g})$. Over all, the 2 cereal crops showed the lowest protein content $(0.00269$ $\mathrm{g} / 100 \mathrm{~g}$ in Setaria italica and $0.00412 \mathrm{~g} / 100 \mathrm{~g}$ in Coix-lacryma jobi) among the three group of the plant sample studied (Table 2).

Carbohydrate content. Table 2 shows the data of the present analysis that revealed, the carbohydrate content in the selected 22 plant samples shows significant variation ranging from $0.198-5.212 \mathrm{~g} / 100 \mathrm{~g}$. The maximum carbohydrate content was recorded in Setaria italica $(5.212 \mathrm{~g} / 100 \mathrm{~g})$ followed by Spondias pinnata fruits $(5.135 \mathrm{~g} / 100 \mathrm{~g})$, Actinidia callosa $(5.135 \mathrm{~g} / 100 \mathrm{~g})$ and seeds of Coix-lacryma jobi $(4.379 \mathrm{~g} / 100 \mathrm{~g})$ and lowest was recorded in the fruits of Juglans regia $(0.198 \mathrm{~g} / 100 \mathrm{~g})$ followed by nuts of Hodgsonia macrocarpa $(0.321 \mathrm{~g} / 100 \mathrm{~g})$ and leaves of Lasia spinosa $(0.417 \mathrm{~g} / 100 \mathrm{~g})$. Over all, the highest carbohydrate content was recorded in the cereal crops amongst the three groups of plants studied.

Reducing sugar. Unlike the other nutritional parameters, in Table 2 the value of reducing sugar content in the 22 plant samples studied does not vary much which ranges from $0.009-0.139 \mathrm{~g} / 100 \mathrm{~g}$ of sample. Reducing sugar content was highest in fruits of Ficus auriculata $(0.139 \mathrm{~g} / 100 \mathrm{~g})$ which was followed by fruits of Actinidia callosa $(0.097 \mathrm{~g} / 100 \mathrm{~g})$ and leaves of Polygonum molle (0.081 $\mathrm{g} / 100 \mathrm{~g})$. Seeds of Coix-lacryma jobi and Juglans regia $(0.009 \mathrm{~g} / 100 \mathrm{~g})$ were found to have the lowest reducing sugar content. It was established that the leafy vegetables and fruits content higher reducing sugar then the cereal crops. Table 2 shows the proximate composition of the 22 selected UEP with the parameters: moisture content, total carbohydrate, reducing sugar and protein content.

Antioxidant activity: Among the 22 UEP studied, maximum antioxidant activity was observed in Terminalia chebula fruits $(37.49 \mu \mathrm{g} / \mathrm{ml})$ followed by leaves of Clerodendrum glandulosum $(65.29 \mu \mathrm{g} / \mathrm{ml})$ and fruit of Phyllanthus emblica $(79.08 \mu \mathrm{g} / \mathrm{ml})$. The nut of Juglans regia $(86.83 \mu \mathrm{g} / \mathrm{ml})$, fruits of Rhus chinensis 
$(84.73 \mu \mathrm{g} / \mathrm{ml})$ and Spondias pinnata $(90.86 \mu \mathrm{g} / \mathrm{ml})$ also showed very high antioxidant activity after Terminalia chebula, Clerodendrum glandulosum and Phyllanthus emblica extracts. The lowest antioxidant activity was observed in the seed of Setaria italica $(994.36 \mu \mathrm{g} / \mathrm{ml})$, nut of Hodgsonia macrocarpa $(698.57 \mu \mathrm{g} / \mathrm{ml})$ and seed of Coix-lacryma jobi $(540.57 \mu \mathrm{g} / \mathrm{ml})$. Figure 1-3, Table 3 shows the graphical representation of antioxidant activities of 22 studied UEP.

Total phenol content (TPC): The maximum TPC was recorded in the fruits of Terminalia chebula (53.11 mg GAE/g) and Rhus chinensis (43.99 mg GAE/g). The TPC value of $T$. chebula and $R$. chinensis varies significantly from the rest of the 20 plant samples as the value of TPC of the other samples which ranges from $0.09 \mathrm{mg}-8.75 \mathrm{mg} \mathrm{GAE} / \mathrm{g}$. The lowest TPC was recorded in the leaves of Elatostema platyphyllum (0.09 $\mathrm{mg}$ GAE/g) followed by the fruit of Ficus auriculata

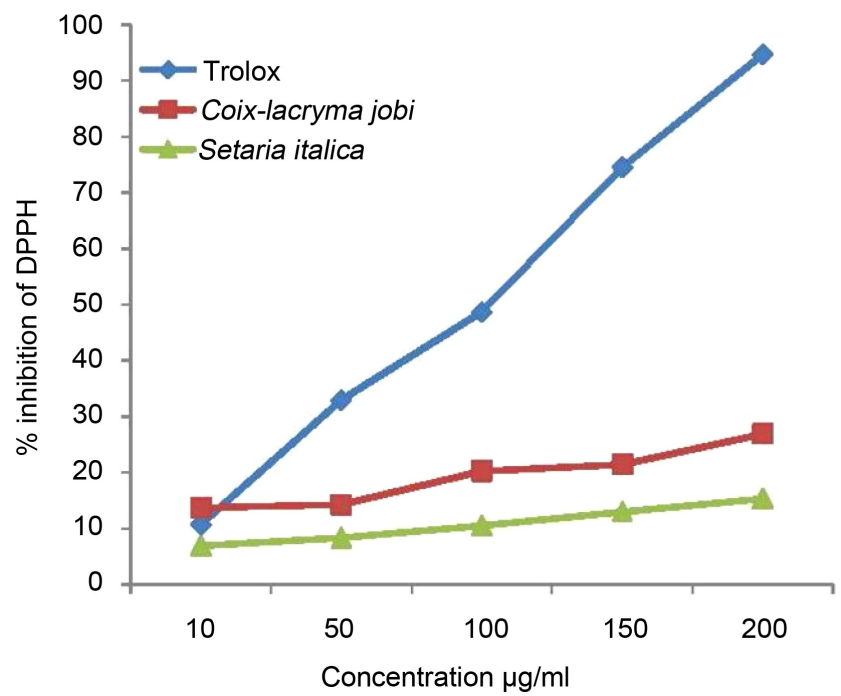

Figure 1. The antioxidant scavenging effect (\% inhibition) of 2 cereal crops (Coix-lacryma jobi and Setaria italica) at different extract concentrations against Trolox on DPPH radicals.

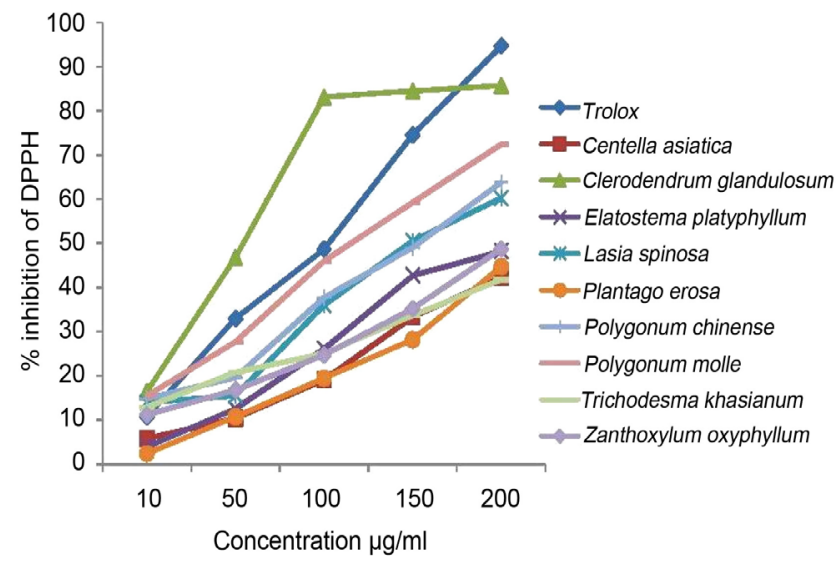

Figure 2. The antioxidant scavenging effect (\% inhibition) of 9 leafy vegetables at different extract concentrations against Trolox on DPPH radicals. 


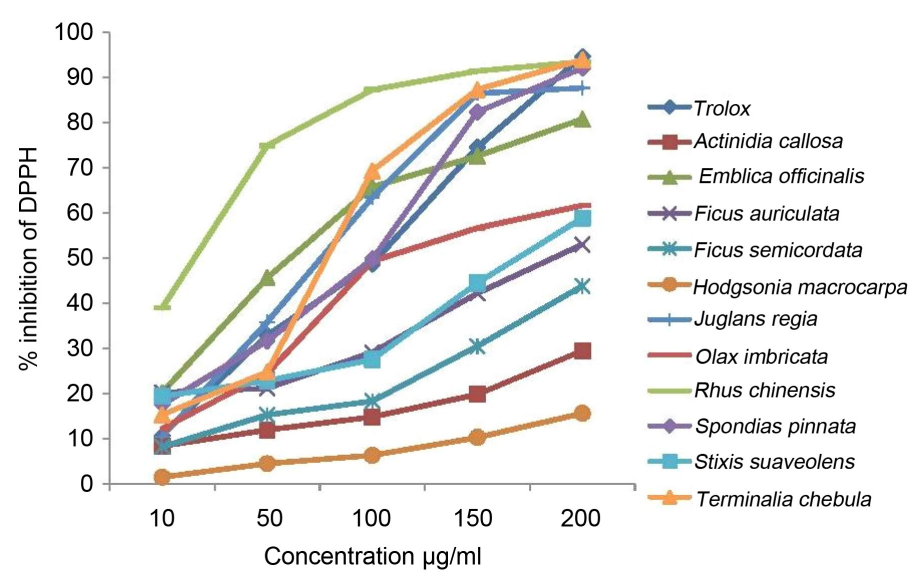

Figure 3. The antioxidant scavenging effect (\% inhibition) of 11 fruits and nuts at different extract concentrations against Trolox on DPPH radicals.

Table 3. Quantification of total phenol content, Total flavonoid content and antioxidant activity of 22 selected UEP.

\begin{tabular}{|c|c|c|c|}
\hline \multirow{3}{*}{ Plant Species } & \multicolumn{3}{|c|}{ Parameters* } \\
\hline & Antioxidant Activity & TPC & TFC \\
\hline & IC50 $(\mathrm{g} / \mathrm{ml})$ & $(\mathrm{g} \mathrm{GAE} / 100 \mathrm{~g})^{*}$ & $(\mathrm{~g} \mathrm{QE} / 100 \mathrm{~g})^{*}$ \\
\hline & \multicolumn{3}{|c|}{ Cereal Crops } \\
\hline Coix-lacryma jobi & 0.000541 & $0.084 \pm 0.002$ & $0.111 \pm 0.01$ \\
\hline \multirow[t]{2}{*}{ Setaria italic } & 0.000994 & $0.101 \pm 0.006$ & $0.043 \pm 0.006$ \\
\hline & \multicolumn{3}{|c|}{ Leafy Vegetables } \\
\hline Clerodendrum glandulosum & 0.000066 & $0.171 \pm 0.005$ & $4.367 \pm 0.06$ \\
\hline Elatostema platyphyllum & 0.000196 & $0.009 \pm 0.002$ & $0.0014 \pm 0.05$ \\
\hline Centella asiatica & 0.000241 & $0.232 \pm 0.006$ & $0.097 \pm 0.14$ \\
\hline Lasia spinosa & 0.000157 & $0.278 \pm 0.05$ & $0.165 \pm 0.01$ \\
\hline Plantago erosa & 0.000238 & $0.155 \pm 0.006$ & $0.004 \pm 0.02$ \\
\hline Polygonum chinense & 0.000151 & $0.409 \pm 0.005$ & $0.524 \pm 0.001$ \\
\hline Polygonum molle & 0.000121 & $0.844 \pm 0.06$ & $0.187 \pm 0.04$ \\
\hline Trichodesma khasianum & 0.000207 & $0.161 \pm 0.002$ & $0.256 \pm 0.009$ \\
\hline \multirow[t]{2}{*}{ Zanthoxylum oxyphyllum } & 0.000219 & $0.40 \pm 0.07$ & $0.686 \pm 0.01$ \\
\hline & \multicolumn{3}{|c|}{ Fruits and Nuts } \\
\hline Actinidia callosa & 0.000421 & $0.212 \pm 0.005$ & $0.002 \pm 0.007$ \\
\hline Phyllanthus emblica & 0.000079 & $0.139 \pm 0.005$ & $0.422 \pm 0.06$ \\
\hline Ficus auriculata & 0.000195 & $0.082 \pm 0.02$ & $0.48 \pm 0.05$ \\
\hline Ficus semicordata & 0.000251 & $0.124 \pm 0.005$ & $0.013 \pm 0.003$ \\
\hline Hodgsonia macrocarpa & 0.000699 & $0.108 \pm 0.003$ & $0.004 \pm 0.001$ \\
\hline Juglans regia & 0.00087 & $0.875 \pm 0.02$ & $0.525 \pm 0.03$ \\
\hline Olax imbricate & 0.000136 & $0.174 \pm 0.006$ & $0.002 \pm 0.006$ \\
\hline Spondias pinnata & 0.00091 & $0.431 \pm 0.004$ & $0.239 \pm 0.007$ \\
\hline Rhus chinensis & 0.00085 & $4.399 \pm 0.24$ & $0.661 \pm 0.005$ \\
\hline Stixis suaveolens & 0.00018 & $0.139 \pm 0.005$ & $0.024 \pm 0.09$ \\
\hline Terminalia chebula & 0.000038 & $5.311 \pm 0.18$ & $2.778 \pm 0.24$ \\
\hline
\end{tabular}


(0.82 $\mathrm{mg} \mathrm{GAE} / \mathrm{g}$ ) and seed of Coix-lacryma jobi (0.84 mg GAE/g). Over all, the TPC of the selected plants samples are almost at the same level except for $T$. chebula and R. chinensis.

Total flavonoid content. The data revealed that the total flavonoid content (TFC) of the plant samples was much lesser than that of the TPC. The TFC from the leaves of Clerodendrum glandulosum (43.67 mg QE/g) and fruit of Terminalia chebula (27.78 mg QE/g) were found to be highest among the 22 plant samples. The TFC of the rest 20 plant samples does not showed much difference from each other as value ranges from $0.04-6.8 \mathrm{mg} \mathrm{QE} / \mathrm{g}$. The lowest TFC was found to be in the nut of Hodgsonia macrocarpa (0.004 mg QE/g) followed by the leaves of Elatostema platyphyllum (0.014 mg QE/g), fruit of Olax imbricata (0.02 mg QE/g), leaves of Plantago erosa (0.04 mg QE/g) and seed of Setaria italica $(0.43 \mathrm{mg} \mathrm{QE} / \mathrm{g}$ ). Table 3 showed the proximate compositions of 22 selected UEP with the parameters: antioxidant activity, total phenol content and total flavonoid content.

\section{Discussion}

With increase in human population there is a growing concern about the food security throughout the world. Forest is an important source of various edible plants which are being used by rural populations throughout the world but their commercial potentials are not been exploited fully due to lack of data on different nutritional parameters. These plants/crops have the potential to fight against poverty and starvation of rural populations and developing countries. Many of the plant species are nutritionally rich, require relatively low investment for production and also contribute significantly in combating the "hidden hunger" and also deliver many health benefits [2] [3].

During present study 22 selected UEPs selected and different nutritional parameters varied significantly. The moisture content of Spondias pinnata, Phyllanthus emblica, Setaria italica, Ficus auriculata and Ficus semicordata in the present investigation are in agreement with the reports of Khomdram [32] [33], while moisture content of Hodgsonia macrocarpa and Lasia spinosa were lesser with the reports of Sundriyal and Sundriyal [34]. Report of moisture percent of Centella asiatica (88\%) by Rosalizan et al. [35] is higher than the present study (80\%). Firdusi [36] reported the moisture content of Lasia spinosa (86.30\%) which comparative higher than the present study $(50.50 \%)$. The reason for this difference could be due to stage and the time of collection of the sample.

Besides moisture content, other nutritional parameters were also investigated in these selected UEPs. In the present study the protein and reducing sugar content of Spondias pinnata, Phyllanthus emblica, Hodgsonia macrocarpa, Terminalia chebula and Zanthoxylum oxyphyllum were found to be much higher compared to findings of Khomdram [32] and Sundriyal and Sundriyal [34]. Protein quality of a food depends on its amino acid content and the physiological utilization of specific amino acid after digestion, absorption and minimal obligatory 
rates of oxidation [37] and that hydrolysis of protein occur during conversion of chloroplast to chromoplast which might have decreased protein content at ripening [38].

The present finding shows that antioxidant activity was higher in the fruit samples then leafy vegetables and cereal crop samples. Findings of Saha and Verma [39] shows higher antioxidant activity and TPC of T. chebula $(14 \mu \mathrm{g} / \mathrm{ml})$ and $(13.4 \mathrm{~g} / 100 \mathrm{~g})$ respectively but lower value TFC $(0.793 \mathrm{~g} / 100 \mathrm{~g})$ than the present study (antioxidant activity $-37.49 \mu \mathrm{g} / \mathrm{ml}$, TPC-53.11 mg/g, TFC-27.78 mg/g). Flavonoid and phenolic content shows better antioxidant activity, as such the maximum antioxidant activity was found to be Terminalia chebula, Rhus chinensis, Clerodendrum glandulosum, Juglans regia and Phyllanthus emblica which also showed the maximum content of Phenolic and/or Flavonoid. Findings of Chalise et al. [40] on T. Chebula, P. emblica and $S$. pinnata are higher than the present findings. Some factors such as habitat where the particular plant has been collected, time of harvesting, storage, ripening, drying and processing etc. may have affects on the antioxidant activity, TPC and TFC as suggested by Chalise et al.

Nagaland with its diverse flora and its forest covering $12,966 \mathrm{sq} . \mathrm{km}$ is home to a large number of underutilized wild edible plants (leafy vegetable, fruit, nuts etc.). The present finding showed that some of the underutilized edibles plants are highly nutritious which are easily accessible and offers a cheaper option over inorganic commercial food products. The UEP were also found selling in local market in fresh form, dried form or roasted or made into a local product which cost around Rs. 20 - 50 per 400 - 500 gm packet and some are in high demand because of its taste, medicinal properties etc. [3]. Though the lifestyle and food habit of modern day has changed significantly with the advancement of Science and Technology, still over $70 \%$ of the population of ethnic tribes of Nagaland are living in rural areas with limited facilities and still depends on forest and forest products for food and health supplements/medicines. They mostly collect the vegetables, cereals etc from the forest for livelihood. These peoples have selected these lesser known forest products by trial and error methods over several generations without knowing the nutritional components. Present study is the first of its kind to know the nutritional parameters of some of the popular UEP of the region.

\section{Conclusion}

In the present investigation, assessment on the nutrient composition, phytochemical and antioxidant properties were carried out in 22 selected underutilized edible plants of Nagaland, India. The present investigation throws some light on the nutritional and antioxidant content of 22 selected underutilized edible plants which will help increase our knowledge on their use. The result from the present investigation can contribute as nutritional support to different region of the state for health improvement and help in development of the various 
value added local product of the underutilized edible plants which can help up-lift the socio-economic status of the local inhabitants of the state. Also, from the result obtained it was observed that many underutilized edible plants have high nutritional composition and antioxidant activity, it will be of great help if more research works are carried out in the future to study the phytochemical and nutraceutical properties of these plants which will help improve the present day medicine and its marketability.

\section{Acknowledgements}

The authors are thankful to Department of Biotechnology, Ministry of Science \& Technology, Govt. of India, New Delhi, India for financial support through Institutional Biotech Hub vide order No. BT/22/NE/2011. Facilities used from the UGC-SAP (DRS-III) and DST-FIST programmes are duly acknowledged.

\section{Conflicts of Interest}

The authors declare that there is no conflicts of interests exist.

\section{References}

[1] Jaenicke, H. and Höschle-Zeledon, I. (2006) Strategic Framework for Underutilized Plant Species Research and Development. International Centre Underutilised Crops, Colombo, Global Facilitation Unit for Underutilized Species and International Plant Genetic Resources Institute, Rome.

[2] Deb, C.R., Khruomo, N. and Jamir, N.S. (2016) A Study on the Documentation and Market Acceptability of Underutilized Wild Edible Crops of Kohima District, Nagaland, India. Asian Journal of Biological Life Sciences, 5, 201-206.

[3] Deb, C.R., Khruomo, N. and Paul, A. (2019) Underutilized Edible Plants of Nagaland: A Survey and Documentation from Kohima, Phek and Tuensang District of Nagaland, India. American Journal of Plant Sciences, 10, 162-178. https://doi.org/10.4236/ajps.2019.101014

[4] Dansi, A., Vodouhe, R., Azokpota, P., Yedomonhan, H., Assgba, P., Adjatin, A., Loko, Y.L., Dossou-Aminon, I. and Akpagana, K. (2012) Diversity of the Neglected and Underutilized Crop Species of Importance in Benin. Scientific World Journal, 2012, Article ID: 932947. https://doi.org/10.1100/2012/932947

[5] Adjatin, A., Dansi, A., Badoussi, E., Sanoussi, A., Dansi, M., Azokpota, P., Ahissou, H., Akouegninou, A., Akpagana, K. and Sanni, A. (2013) Proximate, Mineral and Vitamin C Composition of Vegetable Gbolo (Crassocephalum rubens (Juss ex Jacq) S. Moore and C. crepidioides (Benth) S. Moore) in Benin. International Journal of Biological and Chemical Sciences, 7, 319-331. https://doi.org/10.4314/ijbcs.v7i1.27

[6] Hasler, C.M. (1998) Functional Foods: Their Role in Disease Prevention and Health Promotion. Food Technology, 52, 63-70.

[7] Kaur, C. and Kapoor, H.C. (2001) Antioxidants in fruits And Vegetables-The Millennium's Health. International Journal of Food Science and Technology, 36, 703-725. https://doi.org/10.1111/j.1365-2621.2001.00513.x

[8] Arts, I. and Hollman, P. (2005) Polyphenols and Disease Risk in Epidemiologic Studies. American Journal of Clinical Nutrition, 81, 317S-325S. https://doi.org/10.1093/ajcn/81.1.317S 
[9] Scalbert, A. Manach, C. Morand, C. and Rémésy, C. (2005) Dietary Polyphenols and the Prevention of Diseases. Critical Reviews in Food Science and Nutrition, 45, 287 306. https://doi.org/10.1080/1040869059096

[10] Craig, W. and Beck, L. (1999) Phytochemicals: Health Protective Effects. Canadian Journal of Dietetic Practice Research, 60, 78-84.

[11] Kader, A. (2001) Importance of Fruits, Nuts and Vegetables in Human Nutrition and Health. Perishables Handling Quarterly, No. 106, 4-6.

[12] Wargovich, M.J. (2000) Anticancer Properties of Fruits and Vegetables. Horticultural Science, 35, 573-575. https://doi.org/10.21273/HORTSCI.35.4.573

[13] Panyaphu, K., Sirisa-ard, P., Ubol, P.N., Nathakarnkitkul, S., Chansakaow, S. and On, T.V. (2012) Phytochemical, Antioxidant and Antibacterial Activities of Medicinal Plants Used in Northern Thailand as Postpartum Herbal Bath Recipes by the Mien (Yao) Community. Phytopharmacology, 2, 92-105.

[14] Kahl, R. and Kappus, H. (1993) Toxicology of the Synthetic Antioxidants BHA and BHT in Comparison with the Natural Antioxidant Vitamin E. Zeitschrift für Lebensmittel-Untersuchung und Forschung, 196, 329-338.

https://doi.org/10.1007/BF01197931

[15] Rohman, A., Riyanto, S., Yuniarti, N., Saputra, W.R. and Utami, R. (2010) Antioxidant Activity, Total Phenolic, and Total Flavaonoid of Extracts and Fractions of Red Fruit (Pandanus conoideus Lam). International Food Research Journal, 17, 97-106.

[16] Galketiya, C.T., Weerarathna, S., Punchihewa, J.C., Wickramaratne, M.N. and Wickramaratne, D.B.M. (2017) Screening of Edible Plants in Sri Lanka for Antioxidant Activity. Journal of Medical Plants Studies, 5, 91-95.

[17] Elliott, J.G. (1999) Application of Antioxidant Vitamins in Foods and Beverages. Food Technology, 53, 46-48.

[18] Temple, N.J. (2000) Antioxidants and Disease: More Questions than Answers. Natural Resources, 20, 449-459. https://doi.org/10.1016/S0271-5317(00)00138-X

[19] Ramarathnam, N., Ochi, H. and Takeuchi, M. (1997) Antioxidant Defense System in Vegetable Extracts. In: Shahidi, F., Ed., Natural Antioxidants. Chemistry, Health Effects, and Applications, American Oil Chemists' Society Press, Champaign, 76-87.

[20] Halliwell, B. (1990) How to Characterize Biological Antioxidants? Free Radical Research Communications, 9, 1-32. https://doi.org/10.3109/10715769009148569

[21] Gazzani, G., Papetti, A., Massolini, G. and Daglia, M. (1998) Anti- and Prooxidant Activity of Water Soluble Components of Some Common Diet Vegetables and the Effect of Thermal Treatment. Journal of Agricultural and Food Chemistry, 46, 41184122. https://doi.org/10.1021/jf980300o

[22] Black, R.E., Morris, S.S. and Bryce, J. (2003) Where and Why Are 10 Million Children Dying Every Year? The Lancet, 361, 2226-2234. https://doi.org/10.1016/S0140-6736(03)13779-8

[23] Food and Agriculture Organization of the United Nations (2012) The State of Food Insecurity in the World 2012: Economic Growth Is Necessary but Not Sufficient to Accelerate Reduction of Hunger and Malnutrition. Food and Agriculture Organization of the United Nations, Rome.

[24] Yesodharan, K. and Sujana, K.A. (2007) Ethnomedicinal Knowledge among Malamalasar Tribe of Parambikulam Wildlife Sanctuary, Kerala. Indian Journal of Traditional Knowledge, 6, 481-485.

[25] Association of Official Agricultural Chemists (1990) Approved Methods of Association of Official Analytical Chemists. 11th Edition, Association of Official Agricul- 
tural Chemists, Washington DC, 240.

[26] Lowry, O.H., Nira, J., Rosebrough, A., Lewis, F. and Rose, J.R. (1951) Protein Measurement with the Folin Phenol Reagent. Journal of Biological Chemistry, 93, 265 275. https://doi.org/10.1016/S0021-9258(19)52451-6

[27] Dubois, M., Gilles, K.A., Hamilton, J.K., Rebers, P.A. and Smith, F. (1956) Colorimetric Method for Determination of Sugars and Related Substances. Analytical Chemistry, 28, 350-356. https://doi.org/10.1021/ac60111a017

[28] Miller, G.L. (1959) Use of Dinitrosalicyclic Acid Reagent for Determination of Reducing Sugar, Analytical Chemistry, 31, 426-428.

https://doi.org/10.1021/ac60147a030

[29] Aoshima, H., Tsunoue, H., Koda, H. and Kiso, Y. (2004) Ageing of Whiskey Increases 1,1-diphenyl-2-picrylhydrozyl Radical Scavenging Activity. Journal of Agricultural and Food Chemistry, 52, 5240-5244. https://doi.org/10.1021/jf049817s

[30] Singleton, V.L. and Rossi, J.A. (1965) Colorimetry of Total Phenolics with Phosphomolybdic-Phosphotungstic Acid Reagent. American Journal of Enology and Viticulture, 16, 144-158.

[31] Sahreen, S., Khan, M. and Khan, R.A. (2010) Evaluation of Antioxidant Activities of Various solvent Extracts of Carisa apaca Fruits. Food Chemistry, 122, 1205-1211. https://doi.org/10.1016/j.foodchem.2010.03.120

[32] Khomdram, S. (2007) Studies of the Nutritive Values of the Wild Seasonal Fruits of Manipur. Ph. D Thesis, Manipur University, Canchipur.

[33] Koehler, P. and Weiser, H. (2013) Chemistry of Cereal Grains. In: Gobbetti and Gönzle, Eds., Handbook on Sourdough Biotechnology, Springer, New York, 11-45. https://doi.org/10.1007/978-1-4614-5425-0 2

[34] Sundriyal, M. and Sundriyal, R.C. (2001) Wild Edible Plants of the Sikkim Himalaya: Nutritive Values of Selected Species. Economic Botany, 55, Article No. 377. https://doi.org/10.1007/BF02866561

[35] Rosalizan, M.S., Rohani, M.Y., Khatijah, I. and Shukn, M.A. (2008) Physical Characteristics, Nutrient Contents and Triterpene Compounds of Ratoon Crops of Centella asiatica at Three Different Stages of Maturity. Journal of Tropical Agriculture and Food Science, 36, 43-51.

[36] Firdusi, S.N., Nilima, N. and Borooah, M.S. (2013) Nutrient Composition of Two Nonconventional Greens (Lasia spinosa and Alpinia nigra) of Assam Having Therapeutic Importance. Asian Journal of Home Science, 8, 343-346.

[37] Friedman, M. (1996) Nutritional Value of Proteins from Different Food Sources: A Review. Journal of Agricultural and Food Chemistry, 44, 6-29. https://doi.org/10.1021/jf9400167

[38] Anupa, T., Jaganath, S., Girisha, R. and Mallikarjunagowda, A.P. (2012) Studies on Qualitative Characteristics in Different Genotypes of Apple Colour Guava (Psidium guajava L.). International Journal of Agriculture, Environment and Biotechnology, 5, 109-112.

[39] Saha, S. and Verma, R. (2014) Antioxidant Activity of Polyphenolic Extracts of Terminalia chebula Retzius Fruits. Journal of Taibah University for Science, 10, 805812. https://doi.org/10.1016/j.jtusci.2014.09.003

[40] Chalise, J.Y., Acharya, K., Gurung, N., Bhusal, R.M., Gurung, R., Skalko-Basnet, N. and Basnet, P. (2010) Antioxidant Activity and Polyphenol Content in Edible Wild Fruits from Nepal. International Journal of Food Science and Nutrition, 61, 425432. https://doi.org/10.3109/09637481003591590 